\title{
A Critical Study of the Character and Influence of Musa Kazim al-Husayni During and After the Ottoman Empire
}

\author{
Mu'tasem Hasan Ahmed Naser ${ }^{1}$, Randa Hashem Mohammad Abu Hilal ${ }^{2}$ \\ ${ }^{1}$ Department of History, Al-Quds University, East Jerusalem, Palestine \\ ${ }^{2}$ Department of English, Al-Quds University, East Jerusalem, Palestine
}

Email address:

alnasermutasem122@gmail.com (M. H. A. Naser), rabuhlal@gmail.com (R. H. M. A. Hilal)

\section{To cite this article:}

Mu'tasem Hasan Ahmed Naser, Randa Hashem Mohammad Abu Hilal. A Critical Study of the Character and Influence of Musa Kazim alHusayni During and After the Ottoman Empire. History Research. Vol. 3, No. 4, 2015, pp. 48-53. doi: 10.11648/j.history.20150304.11

\begin{abstract}
This paper aims at examining the character of Musa Kazim al-Husayni's as a national leader that appeared with the advent of British occupation, and after coming into office as Jerusalem mayor. He collided with British authorities that removed him from office, after which he led a Nationalist Palestinian Movement, Nationalist Congresses and Executive Committee. He also led all Palestinian delegations everywhere around the world, and was exceptional in adopting the political approach of action, not the violent one. The researcher adopts the descriptive analytical approaches to shed light on this great character. al-Husayni later realized that this approach is ineffective, but managed to thwart some plans made by the British and moved the whole issue to Europe's capitals. He was the safety valve of the Palestinian Nationalist Movement, despite being a reason for internal conflict, but gained everyone's trust nevertheless. His death signaled the fading of executive committee and national congresses; the most important nationalist movement foundations. The researcher proved that al-Husayni was a unique example of national struggle during that time, where his death was the end of a time and the beginning of a new era for the Palestinian Nationalist Movement.
\end{abstract}

Keywords: Musa Kazem al-Husayni, Nationalist, Palestinian, British, Political, Movement, Struggle

\section{Introduction}

\subsection{Early Life}

Born in Jerusalem in 1853, Musa Kazim al-Husayni completed preliminary and high school education at Rashidya School. He was appointed deputy officer of Gaza Health and Civil Affairs Department by Ottoman Empire and from there headed to Istanbul, but returned two years later without completing his studies. He was sent to Istanbul and attended the Maktab Malkiya [my italic] (State School), the most prestigious Ottoman school that prepares students to hold posts after graduation, as has been stated by the Arab Studies Association (1926).

Al-Husayni obtained great experience and knowledge of the region, as he took many government postings in many countries. His first posting was a clerk in the Department of Health, and then he was appointed the governor (qaymaqam) in 1881. el-Hout (1986) is of the view that he moved throughout Jaffa, Safad, Hazem (Halab region), Acre (Beirut region then) and finally Ajloun (Jordan). Promoted in 1896 as deputy governor (mutasarref), he administered many regions such as Assir, Najd and Saud (Arabian Peninsula), Thalis and Arjmidan (Anadol), Hauran (Syria), al-Muntafaq (Iraq) and finally returned to Syria, where he worked in Hassa and Hauran. Upon his retirement on the eve of World War I, he was given 'Mirmiran' and 'Basha' titles as a tribute by Ottoman authorities, as has been stated by Masoud (1998, p. 86).

\subsection{Mayor Career and Political Action}

Upon the arrival of the British military occupation in Palestine in 1917, Jerusalem municipal council continued local service provision as per Ottoman law. The council had 10 members; six Muslims, two Christians and two Jews, where former mayor Hussein Salem al-Husayni remained in office until his death in January 1918.

During the same month, the British authorities dissolved municipal council and appointed an interim one consisted of six members; two Muslims, two Arab Christians and two Jews, all to reduce influence of Muslims (Halabi, 1993). As a move to win the Arabs on its side, British authorities appointed in 1918 the deceased mayor's brother, Musa 
Kazim al-Husayni, the new mayor. The British conditioned his cooperation, which he refused, as well as refusal to approve Hebrew as an official language at Jerusalem Municipality, whereas one third of council members were Jewish, so that made him the target of their rage (el-Ghouri, 1982). Ishomuddin (May 2014) distinguishes between the party system and political parties and considers them two different concepts. According to him, "The system shows the format of the existence of inter-party politics in a particular political system. Referred to as specific, because of the different political systems in each country or even in a different country from the aspects of its history" (p. 63). This suggests that the conflict in the Palestinian case was within the system and among the parties themselves, which made it very complicated.

\section{Discussion}

\subsection{Nationalistic Interaction}

Arabs started to protest for the first time ever in their modern history. Islamic-Christian associations organized counter-demonstrations over Jewish celebrations of the first anniversary of the Balfour Declaration, November 1918 (Ibid). A Muslim-Christian demonstration on November $3^{\text {rd }}$ led by mayor Musa al-Husayni ended at the government house, where a written protest has been delivered expressing joint refusal by Muslims/Christians to Jewish celebrations as well as their wish for complete independence (Jbarah \& alHusayni, 1995), and another protest was sent to US government, as believed by el-Kayyali (1997). The fact that Musa Kazim led those demonstrations made relations sour between him and Jews.

When the first news on 'King Crane' international committee reached Palestine early 1919, the Islamic Association in Jerusalem called upon demonstrations against the committee to emphasize national demands. Musa Kazim al-Husayni and Islamic-Christian association led a demonstration started at al-Aqsa Mosque, where they were joined by Christians, went for foreign consulates to present memos of national demands, and ended with a speech delivered by Musa Kazim al-Husayni (el-Ghouri, 1972).

With Musa Kazim al-Husayni playing the chief, political leaders held a meeting on April $12^{\text {th }}, 1919$ at Saeed alHusayni's house to discuss demands to be presented to 'King Crane' Committee. It has been agreed that independent Syria should be part of Arab Union, Palestine shall be an integral part of Syria, rulers shall be nationalists as stated by people's wish and country's needs, Zionist immigration and wishes shall be refused, with emphasis that indigenous Jews who exist before war have the same rights and duties as Arabs (Sakakini, 1950).

Musa Kazim al-Husayni kept emphasizing national demands in every occasion possible. A meeting was held in 1919 with head of Zionist Congress Mr. Ussishkin who demanded Palestine split from Syria, which was refused by Musa Kazim al-Husayni. The latter asserted Arab demands that if there is a protection, it should be provided by the Americans and then the British. Musa Kazim al-Husayni reiterated Arab refusal to immigration, privileges granted to Jews and Balfour Declaration. He stated that Arabs will resist these privileges, and that they will not acknowledge concessions made by Faisal to Britain and Zionist Movement.

\subsection{Revolution and al-Husayni's Dismiss}

Commander of British troops in the area called 'the occupied eastern enemy lands' General Paul called upon a meeting with Palestine dignitaries, with Musa Kazim alHusayni on top of the guest-list. The meeting took place on February 20 $0^{\text {th }}$, 1920, where General Paul stated that Reconciliation Conference in Paris has agreed to grant mandate over Palestine to Britain and that Balfour Declaration will be one of the mandate items. He strictly warned them against strike: "There's only one government in this country, which is ME, and I have massive military power that could crush anyone who disturbs order, and I shall use it with no restrictions in the future" (Abu Basir, 1988, p. 16). This made everyone angry and stated they would protest, so anti-Zionism demonstrations broke on February $27^{\text {th }}, 1920$, led by Musa Kazim al-Husayni (el-Muhtadi, 2003).

As a result of Zionist pressure against British authorities, British commander gave on March 11 an order banning demonstrations, which must have increased general discontent amongst Arabs. el-Kayyali (1977) is of the opinion that, as holidays of Christians (Easter), Jewish (Passover) and Muslims (Nabi Musa) coincided, this raised serious concerns among Jewish and British authorities, where it was natural that these occasions would turn into protests and incitement against "Zionism and the British" (p. 147).

Following a tradition, people of Jerusalem descended onto streets on Sunday, April $4^{\text {th }}, 1920$ to receive travelers from Hebron en route to visit Nabi Musa Tomb. The reception was great where people of Jerusalem and outskirts, Nablus and followers of various Christian sects took part. The procession turned into a major national demonstration that hailed Arab state and King Faisal, and called the fall of mandate, Balfour Declaration and Jewish immigration. al-Husayni spoke out of his office balcony followed by speeches from a number of national figures that inflamed masses' feelings. When the demonstration reached Jaffa Gate, some Jewish harassed protesters and bloody clashed broke out between unarmed Arabs on one side and British policemen and Jewish on the other side, which caused many victims and injuries

Following the riots, people of Jerusalem presented a request signed by Jerusalem dignitaries, chief among which Jerusalem mayor al-Husayni, asking the British government to "dismiss Jerusalem ruler Mr. Storrs" (Khilleh, 1974, p. 151). Thus, British authorities accused Musa of orchestrating strikes, as he became - from their perspective - the leader and spokesman of the opposition against mandate, bearing in mind he opposed adopting Hebrew as an official language at Jerusalem Municipality. Storrs warned by asking him to choose between politics and mayor. However, the warning 
was in fact a deadline for Storrs to find al-Husayni's replacement, who was Raghib Nashashibi. Nashashibi refused to sign the request, where it has been said that he was advised to do so, a fact that became evident by accepting the mayor posting once asked by Storrs. Twenty minutes after Nashashibi has been given post, Storrs summoned Musa Kazim to tell him about the replacement, Musa Kazim replied: "Your Excellency has the free well to do that, but I recommend waiting as I am sure that no Arab would dare to take my place". This is where the military governor handed him Raghib Nashashibi's acceptance, as has been stated by el-Hout (2000), stating Musa Kazim's dismissal.

AL-Husayni believed that no one among Jerusalem dignitaries would accept the post, as Emil el-Ghouri actually asserted that the government offered mayor post to many dignitaries, who turned down that offer (el-Ghouri, 1972). However, the fact that chief of Nashashibi clan Raghib Nashashibi accepted the offer marked a new turn in nationalist movement and the rivalry with al-Husayni clan. According to Mahafzah (1981), Since, Musa Kazim has been seen as leader of nationalist Palestinian movement, especially after being chosen by the "third nationalist Palestine Arab Congress as chairman, as well as chairman of emanating executive committee" (p. 27).

\subsection{Leader of National Conferences}

Following 1920 revolution, overthrow of Faisal government and San Remo resolutions that divided Great Syria between France and Britain, the third nationalist Palestine Arab Congress was held in Haifa from December 13-19, 1920, where "Jerusalem was represented by Musa Kazim al-Husayni” (Zua'iter, 1979, p. 42).

The Congress was special in that membership was restricted to Palestinians, denoting that Palestine has become an independent political entity that has specific political needs and requirements. Therefore, a political leadership for Arab Palestine has been elected and called 'the Executive Committee', which included nine members, and Musa Kazim al-Husayni was elected chairman despite he did not get enough votes, but for gaining national consensus especially after dismissal from Jerusalem mayor post. He won Christians' support too as Orthodox Romans invited him to chair a meeting in Ramallah, where he delivered an impassioned and profound speech.

After Jaffa revolution, May 1920, the Executive Committee wanted to hold a referendum for the Arab people of Palestine to express opinion and will, so it called for the fourth nationalist Palestine Arab Congress in Jerusalem, May $29^{\text {th }}, 1921$, where he was elected chairman, and also at the fifth congress, held August 1922 in Nablus. Upon return from Europe, he delivered a speech at the congress reiterating the willingness for negotiations in Britain, and that they are many supporters to Arab issues in Britain and France. The High Commissioner said that many participants were calling for Palestine and against Balfour Declaration and Zionism, but Musa Kazim refrained from inciting against Britain and violence too as a way to fight Britain's pro-Zionist policy (el-
Kayyali, 1977).

The sixth nationalist Palestine Arab Congress was held on June $18^{\text {th }}, 1923$ in Jaffa with al-Husayni as chairman, which agreed to reject draft English treaty presented to Hussein of Hejaz as it violated promises made to Arabs and rights of the Palestinian people, and demanded revocation of pro-Zionist policy and instating an independent representative national government (Arab Studies Association, n. d.). The congress decided to form a delegation headed by Musa Kazim to go to London and have contacts with members of the parliament and ministry of colonies. The congress also discussed refrain from paying tax to the government (Khilleh, 1974).

It was evident that al-Husayni's character influenced decisions made at congresses, which concentrated on political struggle, as expressed by the High Commissioner. According to Onyesom and Igbesi (2015) "Management of conflicts covers the entire handling of conflict positively through its different stages, including efforts made towards prevention by being proactive, conflict limitation, containment and litigation" (p. 254). And this was not the case with the Palestinians. However, al-Husayni has been successful at thwarting instate of a parliament and advisory council. Upon meeting the High Commissioner on October $11^{\text {th }}, 1923$, Musa Kazim stated that Arab Agency "does not fulfill the people's expectations" (Palestine Newspaper, 1923, p. 313). And that Arabs will never recognize the Jewish Agency and they do not wish to have an agency with same description and functions.

The Palestinian Nationalist Movement suffered severe crisis and division between the two councils and the opposition. The Palestinian leadership could not hold seventh congress until Musa Kazim al-Husayni, who gained national consensus, took initiation. In 1927, and as has been written in the Arab League Journal (1927), Musa Kazim declared wish for reconciliation and put an end to dispute between nationalists, which brings no good to any of them but for enemies of the state. Musa Kazim met a number of nationalists in May 1928 and it has been decided to hold the congress June $15^{\text {th }}$ in Jerusalem, and Musa Kazim was elected chairman of organizing committee (Khilleh, ibid, p. 281). The committee was indeed able to bring together leaders of the two councils and the opposition in June 1928 at Musa Kazim's house, and it has been agreed to hold the conference on June $20^{\text {th }}, 1928$ in Jerusalem under Musa Kazim's chairmanship, who was elected president of executive committee, according to Safari (1933). The only thing that attendants agreed on was al-Husayni, who could bring the leaders of the Palestinian Nationalist Movement together and chair respective congresses.

\subsection{Leader of Palestinian Delegations}

From the beginning, al-Husayni relied in his political approach on division between Britain's policy and Zionism policy, as pragmatism was in need in early 1920s. Despite difficulties the executive committees faced when forming representative official delegations due to controversies. He was successful in chairing the first Palestinian delegation in 
March 1921 to present Palestine's demands at the British Congress in Cairo, chaired by minister of colonies Winston Churchill. In Mahafzah's (1989) point of view, the latter grudgingly met the delegation, but refused to discuss political issues, stating that he "intends to meet the delegation on March $28^{\text {th }}$ in Jerusalem" (p.43). The meeting took place on schedule, during which the delegation presented an extended memorandum concluded the five key demands; cancel the 'Jewish National Home', stop immigration, stop land selling, instate a nationalist Palestinian government that is held accountable before the parliament and keep Palestine united with neighboring countries. Churchill advised Arabs to accept Balfour Declaration as they do not have any other choice (el-Hout, 1986).

The Executive Committee was responsible for the formation of Palestinian delegations heading for Europe, as it believed there is a need to reveal facts in front of the Western public opinion in general and public opinion in Britain in particular, in addition to the need to present the nation's demands. al-Husayni led the first delegation in July 1921, where agenda included meeting the Pope, minister of colonies Winston Churchill, Lowell George, many lords and MPs, senior officials, politicians and media men (Palestine Newspaper, 1921).

Delegation also met Zionist Commission leader Chaim Weizmann as a result of pressure practiced by British colonies ministry. The delegation withdrew, though, after Weizmann's confirmation that "existence of Jews is a right, not a grant" (Khilleh, 1974, p. 22).

al-Husayni led a delegation to Lausanne in October, 1922, trying - unsuccessfully - to win Turkey to the Palestinians' side. Turkey has not been able to stand against Britain, which made delegation get back to London in June 1923, armed with empathy of some officials at the ministry of colonies and with some articles published in Times Newspaper (elKayyali, 1988, p78). And according to el-Hout (1986), alHusayni relied on Sharif Hussein-British government negotiations, but the delegation went home when proven failure" (p. 173).

Executive Committee had deliberations since late 1929 to exploit circumstances brought by Boraq riots, especially report presented by Shaw Committee, which was regarded great success for Arabs. Predictably, the Executive Committee relied on Britain's justice and formed a Palestinian delegation to go to London. Formation was difficult, however, due to disagreement between members of Executive Committee, as proven by refusal to al-Husayni's leadership of delegation that has been agreed on January $9^{\text {th }}$, 1930. The reason behind that was successful maneuver made by Hajj Amin al-Husayni, who openly decided to stand against head of Executive Committee. However, and due to coalition that included al-Husayni's opponents and supporters, and Committee "had to change decision and appointed al-Husayni the delegation head," a valid opinion expressed by Beleg (1991, p. 61).

The delegation was not properly received upon arrival at London on March $30^{\text {th }}, 1930$, but managed to meet the
British Prime Minister Ramsey McDonalds and lord Basified, where delegation demanded establishing a representative nationalist government according to article 22 of League of Nations statute, enact special legislation preventing non-Arabs from buying lands and stop Jews immigration. McDonald, on the other hand, made it clear for the delegation that those demands would never be approved, as they contradict with British Mandate instrument and commitments of the British government to the Zionist Commission. He then reiterated that Balfour Declaration is an irreversible British obligation, and that the British Government is determined to fulfill that obligation. This is where negotiations between the delegation and the British government representatives terminated. Subsequently, Musa Kazim was disappointed by the British policy, considering that it 'is a pro-Zionist policy that ignored Palestinians' rights'. 'Our people will resist this policy by all peaceful means necessary', Musa Kazim said, as has been viewed by Shbeib (1988, p. 9). It was evident that he acknowledged he was wrong when he relied on the change in Britain's attitude, so this was the last Palestinian delegation to Britain. "The seeds of confrontation exist in each person and it is caused by the people's desire to impose their will on their fellow men" (Orzeaţă, 2014, p. 8). This is what al-Husyani understood very well and was trying to resolve with the British.

\subsection{Last Days}

It seemed that there have been consequences to disagreement over establishing the third Palestinian delegation. al-Husayni resigned from the Executive Committee's chairmanship in May 1930, where Arab newspapers attributed that to old age and deteriorating health, whereas 'Palestine' Newspaper viewed that his resignation was because that Mufti turned against him, and the latter aimed at electing a chairman at his disposal; therefore, he withdrew his resignation. On the contrary, he continued political action and sent a letter to Mr. Yeng on October $31^{\text {st }}$, 1931 "to protest against the British policy of allowing Jews buy Arab land, asserting that this is dangerous for the holy lands," said Jbarah (1995, p. 211). According to Borat (1918), "Musa Kazim was the president of the Nation Fund committee, founded September 1932, to raise funds in order to buy lands in Palestine to keep them from falling into Jews' hands" (p. 190).

Jewish immigration raised Arabs' concerns, which convinced Palestinians that they should fight the British directly. Therefore, secret meeting took place in Jerusalem where the Executive Committee, headed by al-Husayni, was called to declare protests (el-Ghouri, 1972, p. 159). Against that public pressure, al-Husayni, in the name of Executive Committee, called the nation for strike throughout Palestine on October $13^{\text {th }}, 1933$, and to hold major demonstrations in Jerusalem without applying to the government for license, expressing “Arab's despair from the government's policy, and decided to abandon useless speeches" (el-Kayyali, 1988, p. 337). Marches took to the streets of Jerusalem and Jaffa despite the British authorities declared on October $10^{\text {th }}$ that 
they would not allow them, so "the police cracked down brutally and caused many injuries, Musa Kazim being one of them" (Safari, 1933, p. 211)

Al-Husayni stayed at home following his wounds, and died five months later of illness and loneliness. According to el-Hout (1986), he was wrapped in the Arab flag and the mass funeral walked the streets of Jerusalem" (p. 297). He was buried on March $27^{\text {th }}, 1934$ in al-Khatonya School near Iron Gate west of al-Aqsa Mosque (Jameel, 1998, p. 89). His death left a deep impact on the morales of the Executive Committees members and on their status as a whole. The Committee gave out a statement: "Arabs of Palestine are totally frustrated by the British Government; they do not ask it for anything and do not want anything from it" (Shbieb, 1988, p. 14).

The death of this great figure took out the safety valve between the two councils and the opposition under the Executive Committee, as al-Husayni was known for his great ability to spread reconciliation spirit among different parties. He was an example for rising above tribal and factional sensitivities. The annual report for 1934 of the British Government, described him as the leader of the Nationalist Movement since the advent of occupation, until his death, and he won the respect of all Arab people groups of Palestine; his impartiality and fairness raised him above personal interest. According to Atiah (1985), “Once Musa Kazim vanished from the political arena for good, his absence signaled the beginning (or recommence) of rivalry between the two camps" (p. 13). Hussein Fakhri al-Khalidi wrote in his memoires: "with his death, a lofty foundation of struggle collapsed, if not the only foundation, and was mourned by all Arabs of Palestine" (el-Hout, 1986, p. 14).

\section{Conclusion}

As the research has proven, it was evident that alHusayni's death was the end of an era and the beginning of another new era in the Palestinian Nationalist Movement, and a radical change in the nationalist movement's approach throughout the 1920s (count on change of the British Government attitude to Zionist plans), which made the Palestinians clash with the British, a fact symbolized by the Great Palestinian Revolution in 1936. The death of this man can be considered as a great loss to the Palestinians in general, simply because he was a man of great experience and knowledge of the region, and took many government postings in many countries, unlike many others who didn't have his experience. His death of illness and loneliness made the Palestinians more sympathetic and raised the status of this man into a national hero. A good leader's death can affect the country's political and economic aspects and may lead to instability, and the death of al-Husayni affected both these aspects in the Palestinian spheres. As the man had the ability to resolve conflicts and maintain peace among the various conflicting parties or tribes, his death was a blow to peace and stability in the region, and left the Palestinians with the feeling of nostalgia for a glorious past, and for someone who could be counted on in hard times.

\section{Acknowledgement}

This research is supported by the Deanship of Scientific Research and Graduate Studies at Al-Quds University, East Jerusalem-Occupied Palestinian Territory

\section{References}

[1] Budieri, Khalil. Sixty Six Years in \& with Nationalist Palestinian Movement, Saladin Publications, Jerusalem, 1982.

[2] Basir, Saleh Musa. Palestinian People Struggle throughout Half a Century, Bayader Publications, edition III, 1988.

[3] Borat, Yoshuah. Arab Palestinian Struggle (1918-1939), copy at Palestinian Studies Association, Jerusalem.

[4] Beleg, Tsevi. The Grand Mufti, translated by Mustafa Kabaha, el-Aswar, Akka, 1991.

[5] Jbarah, Tayser. Hajj Amin al-Husayni, Erfan Press, Irbid, 1995.

[6] Ishomuddin. (May 2014). Continuity and Change of Political Culture: Study on Scientific Insights and Political Understanding on Politicians of Political Parties in Indonesia. Asian Social Science; Vol. 10, No. 16; 2014. doi:10.5539/ass.v10n16p61， pp. 61-70. Retrieved from http://dx.doi.org.

[7] Halabi, Osama. Jerusalem Arab Municipality, Palestinian Academic Association for International Affairs, Jerusalem, 1993.

[8] el-Hout, Bayan Nuihed. Political Leaders \& Organizations of Palestine (1917-1948), edition III, Palestinian Studies Foundation, Beirut, 1986.

[9] Khilleh, Kamil. Palestine \& British Mandate (1922-1939), PLO Research Center, Beirut, 1974.

[10] Onyesom, M and Igbesi E. F. (2015). Conflict Resolution and Management: The Macro Perspective. Journal of Investment and Management. Vol. 4, No. 5, 2015, pp. 250-255.doi: 10.11648/j.jim.20150405.25. Retrieved from http://www.sciencepublishinggroup.com.

[11] Zua'iter, Akram. Documents of Nationalist Palestine Movement (1918-1939), Palestinian Studies Foundation, p42, Beirut, 1979.

[12] Safari, Essa. Palestine Between Mandate \& Zionism, New Palestine Library, Jaffa, 1933.

[13] Sakakini, Khalil. 'Kaza Ana Ya Dunia', prepared by Hala Sakakini, Commercial Press, Jerusalem, 1950.

[14] Shbeib, Samih. Executive Committee of Palestine during the British Mandate, Palestinian Journals, issue 180, 1988.

[15] Atiah, Ali Masoud. Palestinian Arab Party \& Nationalist Defense Party (1934-1937), Arab Studies Foundation, Jerusalem, 1985.

[16] El-Ghouri, Emil. Sixty Years of Palestine, Part II, Nahar Press, Beirut, 1972. 
[17] El-Ghouri, Emil. Palestine Saga of Sacrifice: Palestinians' Struggle against Colonialism \& Jews (1918-1948), High Arab Commission of Palestine.

[18] El-Kayyali, Abdul Wahab. Modern History of Palestine, edition II, Arab Foundation of Studies \& Publishing, Beirut, 1977.

[19] El-Kayyali, Abdul Wahab. Palestinian Resistance Documents (1918-1939), Palestinian Studies Foundation, Beirut, 1988.

[20] Mahafzah, Ali. Social Brakes of Nationalist Palestine Movement (1918-1936), Arab Future, Year 4, issue 34, 1981.

[21] Mahafzah, Ali. Political Thinking in from end of British Ruling to end of British Mandate (1918-1948), Amman, 1989.

[22] Masoud, Qadari Jamal Jameel. al-Husayni Clan in Jerusalem (1918-1939), Masters degree dissertation, Yarmouk University, 1998.

[23] El-Muhtadi, Abla. Jerusalem \& British Military Ruling (19171920), al-Shorouq Press, Ramallah, 2003.
[24] Orzeață, M. (2014). Living in Perpetual War but Dreaming at Perpetual Peace. International Journal of Literature and Arts. Special Issue: Discourses of Militarization and Identity: Literature of Conflict. Vol. 2, No. 6-1, 2014, pp. 8-14. doi: 10.11648/j.ijla.s.2014020601.12. Retrieved from http://www.sciencepublishinggroup.com.

[25] Nuihed, Ajaj. Men of Palestine. Occupied Palestine Publications, Beirut, 1981.

[26] [Mahdi F. Abdul Hadi. Palestine Documents, Vol 1, PASSIA, Jerusalem, 1997.

[27] Arab League journal, Jerusalem, 1927-1932.

[28] Orient Mirror Daily, Jerusalem, 1919-1933.

[29] Palestine Newspaper, Jaffa, 1911-1932.

[30] Documents of Arab Studies Association, Jerusalem. 